\title{
Entrepreneurial Intention of Sari Mutiara Indonesia University Student In Medan
}

\author{
Rosanna Purba \\ Faculty of Economic and Social Sciences \\ Sari Mutiara Indonesia University
}

\begin{abstract}
This study examined factors that influence the entrepreneurial intention of college students by using the analysis model that consists of three factors namely personality factors, contextual factors, and demography factors in Sari Mutiara Indonesia University. Research using survey questionnaires data collection by using an accidental sampling technique with the samples of this research are all the students as much as 360 students from 20 different majors. Results of this study showed that : (1) There is a significant effect between the personality factors, such as locus of control and need for achievement with entrepreneurial intention of college students; (2) There is a significant effect between the contextual factors, such as subjective norms and instrumental readiness with entrepreneurial intention of college students; and otherwise (3) There is no effect of demographic factors on the entrepreneurial intention of college students.
\end{abstract}

Keywords: Entrepreneurial intention; Personality factors; Contextual factors, Demographic factors

\section{Introduction}

Lately, the topic of entrepreneurship has become one of the interesting topics to be observed more deeply. Along with the development of a country, moreover followed by an increase in the number of population will result in the narrowing of employment opportunities so that it will increase the number of unemployed. The number of unemployed from year to year is also increasing, which will undoubtedly have a negative impact on economic growth and national stability.

Figure 1. Open Unemployment Rate of Indonesia Agt 2016 - Feb 2018

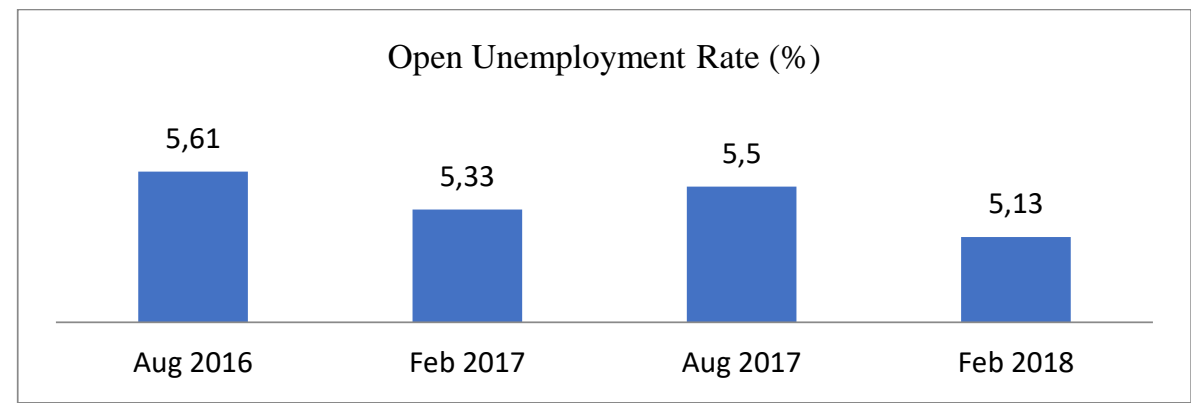

Source: Statistics Indonesia (2018) 
Based on Figure 1 above, the open unemployment rate is $5.13 \%$. Indeed, the graph shows that there is a decrease in the unemployment rate of 140 thousand people. The number of the labor force in February 2018 was 133.94 million people up 2.39 million people compared to February 2017. This data was obtained from BPS (Statistics Indonesia). Although the number is decreasing, it still has to make various efforts to minimize the number of unemployed because it causes limited employment opportunities, especially for intellectuals, namely college graduates. Conditions like this will get worse due to the global competition situation, namely the MEA (ASEAN Economic Community), where domestic graduates will compete with overseas graduates. It shows that students must be equipped, directed, and supported with adequate knowledge in order to foster the spirit of entrepreneurial students before graduating from college so that after graduating students not only focus on finding work but also creating new jobs.

Aside from being an effort to reduce unemployment, entrepreneurship is also one of the motors driving a country's economic growth. President Joko Widodo at a meeting with members of Indonesian Young Entrepreneurs Association, HIPMI (Himpunan Pengusaha Muda Indonesia) throughout Indonesia at the Merdeka Palace, Jakarta on April 5th, 2018 said that the number of entrepreneurs in Indonesia is still far below developed countries that have standards above $14 \%$ while in Indonesia still $3.1 \%$ so that efforts need to be made to accelerate by involving local entrepreneurs and regional entrepreneurs from among young people (Kompas, 5 April 2018). It is hoped that the development of young entrepreneurs is directed to the nation's youth groups who are intelligent and educated. Students must be motivated in order to foster their intention for entrepreneurship (entrepreneurial intention).
According to Zimmerer et al. (2008), adolescents and those in their early 20s (millennials, who were born after 1982), showed high interest in entrepreneurship. The camps of young entrepreneurs have sprung up all over the country to teach young people how to launch and run businesses, and many of them fulfill their dreams. It is expected that students who will be studied who are millennial generation will become young entrepreneurs of the present and the future. Thus, the topic of entrepreneurial intentions needs to be investigated regarding the factors that influence entrepreneurial intentions among students in this case Sari Mutiara Indonesia University in Medan, which consists of four faculties, one postgraduate program, and twenty study programs. The implementation of this research will refer to some previous research that has been done to examine the factors that influence interest in entrepreneurship among students.

\section{Literature Review}

Entrepreneurship is an interesting topic to study because this is very important for Indonesia concerning the development of attitudes and abilities for entrepreneurship. Various researches from various disciplines have also been carried out which have added and developed theories about entrepreneurship. According to Hendro (2011), entrepreneurship is not a science for trading, but more than that. Entrepreneurship such as 'big ship' is full of meaning and meaning in it many lifeboats can save your life if 'storm' comes. Entrepreneurship is a reasonably old profession in this world. This profession has existed since the exchange of goods or bartering in everyday life and continued after the discovery of an exchange of goods called coins, both with gold or paper money standards. Understanding entrepreneurship has evolved as various efforts are made to examine the various developments that 
exist along with the rapid development of technology.

Entrepreneurs are defined as a dynamic process of vision, change, and creation. The application of energy and enthusiasm for the creation and implementation of new ideas and creative solutions is basically needed. The main key consists of a willingness to take risks that are carefully calculated in terms of time, equity, or career; the ability to come up with an effective business team; creative skills to provide the resources needed; the skills needed to build a solid and good business plan; and finally, a vision to identify opportunities when others see them as chaos, contradiction, and confusion (Kuratko, 2009).

According to Suryana (2008), entrepreneurs are people who dare to face risks and like challenges. It is in line with Kasmir (2011) who also revealed the same thing that entrepreneurs are people who are brave enough to take the risk of opening a business on various occasions. Based on many studies that have been carried out both at inside and outside of country related to entrepreneurship, it can be concluded that entrepreneurial intention is influenced by various factors both from internal and external factors that can be seen in an integrated framework. According to Hendro (2011), there are several factors that influence a person's desire to be an entrepreneur: (1) individual/personal factor; (2) work atmosphere; (3) education level; (4) personality; (5) educational achievements; (6) family encouragement; (7) environment and association; (8) want to be more appreciated or self-esteem; and (9) compulsion and circumstances.

Mat, et al. (2015) identify factors that influence entrepreneurial intentions are the locus of control, need for achievement, subjective norms, instrumental readiness, attitude towards entrepreneurship, and perceived support and barriers. The results showed that the factors that greatly influenced the entrepreneurial intentions of mechanical engineering students at the
University of Kuala Lumpur were the locus of control, need for achievement, and subjective norms.

The research of Suharti and Sirine (2011) investigates factors that influence the interest of Satya Wacana Christian University students in pursuing the business world by analyzing models that include internal factors, attitude factors, and contextual factors. The results showed that attitude factors significantly influence students' interest in entrepreneurship. This research also proves the vital role of contextual factors on students' intentions for entrepreneurship.

Research conducted by Indarti and Rostiani (2008) at three universities from three different countries, namely Indonesia, Japan, and Norway concluded that selfefficacy affects entrepreneurial intentions in Indonesian and Norwegian students. Instrument readiness and work experience are key factors influencing Norwegian students for entrepreneurship. Conversely, the factors that influence Indonesian students in entrepreneurship are educational backgrounds. Furthermore, the need for achievement, age, and gender does not significantly influence entrepreneurial intentions.

\section{Personality Factor}

In this study, there are two factors related to personality that will be used as variables that influence entrepreneurial intentions, namely: locus of control (Mat, et. Al., 2015) and need for achievement (McCleland, 1976). McClelland (1976) introduced the concept of the need for achievement (N-Ach) or the need for achievement as a psychological motivation. McClelland stated that individuals with high achievement needs are called gamblers. They set challenging targets for themselves and will take the risk to achieve the set targets in various innovative ways of doing the work. They consider achieving goals as rewards for exceeding financial rewards. These criteria are indeed very 
suitable for the characteristics of entrepreneurs.

Mat et al. (2015) show that locus of control is a factor that significantly contributes to entrepreneurial intentions in mechanical engineering students at Universiti Kuala Lumpur. The concept of locus of control, according to Kreitner and Kinicki (2005) is one personality variable that is defined as the individual's confidence in being able to control one's destiny. The control locus is the level at which individuals are convinced that they are the determinants of their destiny. Localized internal control is an individual who believes that they are in control of whatever happens to them, while an external control locus is an individual who believes that whatever happens to them is controlled by external forces such as luck and opportunity (Robbins and Judge, 2007).

\section{Contextual Factors}

Contextual factors are also factors that are thought to influence entrepreneurial intentions. There are several contextual factors used in this study, namely: subjective norms (Ajzen, 2012), and instrumental readiness (Indarti and Rostiani, 2008 and Mat, et. Al., 2015). Subjective norms (subjective norms) are individual perceptions of social pressure to do or not conduct a behavior (Ajzen, 2012). Research conducted by Mat et al. (2015) shows that subjective norms influence entrepreneurial intention (entrepreneurial intentions).

Access to capital, information, and social networks is referred to as instrumental readiness. According to Indarti and Rostiani (2008) and Mat, et al., (2015), access to capital, information, and social networks is considered as environmental factors that influence entrepreneurial intentions. It is also in line with Darmanto's (2014) finding that instrumental readiness influences students' entrepreneurial intentions. Access to capital is an essential thing to survive. It is an obstacle often faced by novice entrepreneurs in starting a new business because it is usually very dependent on personal savings or obtaining loans from family or friends. Capital limitations are also caused by a lack of support from financial institutions which generally occur in developing countries because businesses have also just started so that no guarantee can be given. Previous empirical research states that access to capital is one of the determinants of a business's success (Kristiansen et. Al., 2003; Indarti, 2004).

Access to business information is an essential factor that encourages the birth of new entrepreneurs. Access to information shows the ability of entrepreneurs to obtain information to achieve goals and overcome problems in business. Singh and Krishna (1994) research prove that a strong desire to obtain information is one of the main characters of an entrepreneur in India. Access to information is not limited to the internal environment of the company but also the external environment as well.

Social networks are business facilities that play a vital role in business success. Entrepreneurs must build and even have strong social interactions and personal relationships as a system of business continuity support. Kristiansen, et al. (2003) explained that social networks that consist of formal and informal relationships between the main and supporting actors in a related circle and describe the pathway for entrepreneurs to gain access to the resources needed in the establishment, development, and success of the business.

\section{Demographic Factors}

Demographic factors are no less important than the two previous factors. The three groups of personality, contextual, and demographic factors are integrated factors in each other in terms of influencing entrepreneurial intentions. The demographic factors that will be used in this study are gender, age, educational 
background, parental work, and entrepreneurial experience. Some previous studies show that demographic factors such as gender, age (Johnson, et. Al., 2010); gender, field of study, parental work, and entrepreneurial experience (Suharti and Sirine, 2011); gender, age, educational background, and work experience (Indarti and Rostiani, 2008) affect entrepreneurial intentions.

\section{Conceptual Framework}

Based on the above description of the theory, the following is the conceptual framework that will be used in this study:

Figure 2. Conceptual Framework

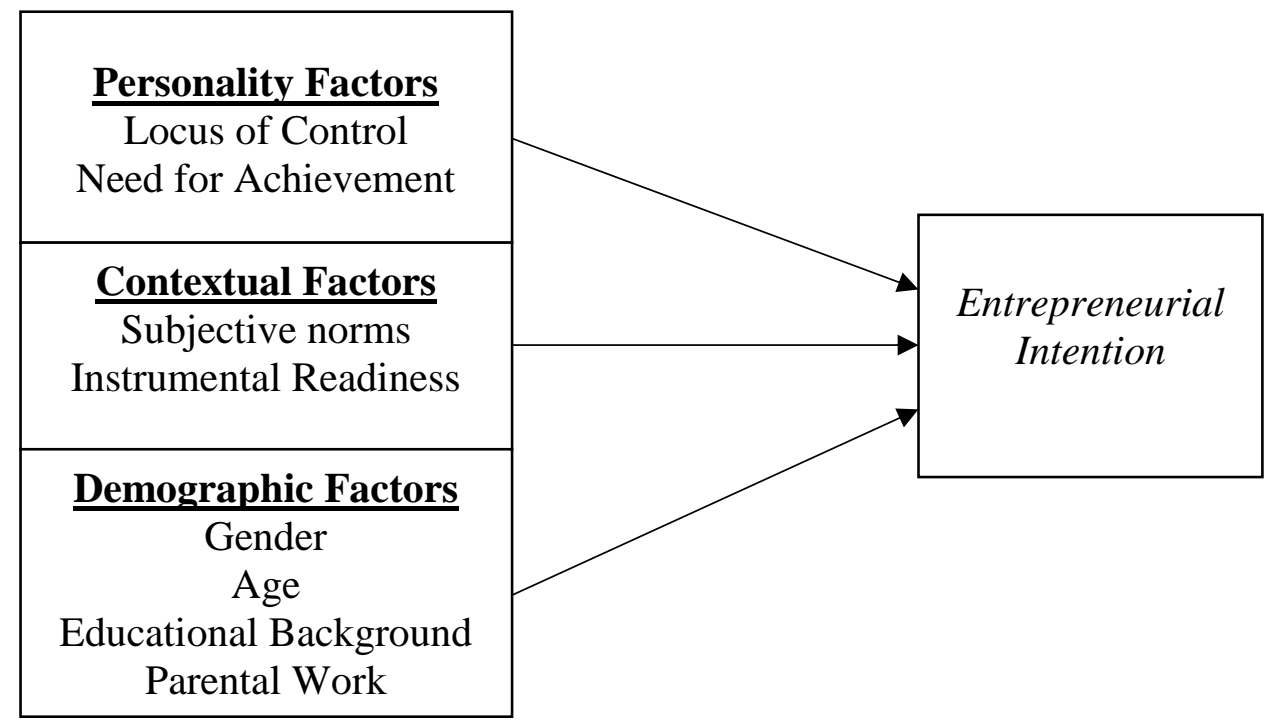

\section{Research Hypothesis}

Based on the conceptual framework above, the following is the formulation of the hypothesis to be tested in this study:

1. Hypothesis 1: Personality factors, namely locus of control (H1.1), need for achievement (H1.2) influence on entrepreneurial intention.

2. Hypothesis 2: Contextual factors, namely subjective norms (H2.1), instrumental readiness $(\mathrm{H} 2.2)$ influence on entrepreneurial intention.

3. Hypothesis 3: Demographic factors, namely gender (H3.1), age (H3.2), educational background (H3.3), parental work (H3.4), and entrepreneurial experience $(\mathrm{H} 3.5)$ influence on entrepreneurial intention.

\section{Research Methods}

The study population were all students of Sari Mutiara Indonesia University with 3,567 students from one postgraduate program and four faculties namely the Faculty of Economics and Social Sciences (Fakultas Ekonomi dan Ilmu Sosial-FEIS) as a business faculty and non-business faculty namely the Faculty of Pharmacy \& Health Sciences (Fakultas Farmasi \& Ilmu Kesehatan-FFIKES), Faculty of Science, Technology and Information (Fakultas Sain, Teknologi, dan Informasi-FSAINTI), and the Faculty of Education (Fakultas Ilmu Pendidikan-FIP). All faculties provide entrepreneurship courses. The sample used was 360 students who were selected using purposive sampling technique and determining the number of samples using the Slovin formula. This research is explanatory 
research and causality. This study uses primary data collected using a structured questionnaire which is divided into four parts: personality factors, contextual factors, demographic factors, and entrepreneurial intentions. The research instrument consists of three research variables that are operationalized through several statements. Personality factor measurement instrument uses nine statements and contextual factors using seven statements, the following instruments to measure the variables of entrepreneurial intentions using three statements. So that overall, there are nineteen statements used in this study. Each statement item will be measured using a 5-point Likert scale by asking the respondent to answer with a choice between 1 - 5 ( 1 = strongly disagree to $5=$ strongly agree). The questionnaire was adapted from several previous studies that are relevant to this study, such as Indarti and Rostiani (2008), Suharti and Sirine (2011), Mat, et al. (2015). Also, the respondent's information regarding gender, age, educational background, parental work, and entrepreneurship experience was collected.

\section{Results and Discussion}

\section{General Profile of Respondents}

This study uses five items of respondents' characteristics, namely, gender, age, educational background, parental work, and entrepreneurial experience. The data to be analyzed is obtained from 360 respondents. The general profile of respondents used were as follows: male students as many as 122 people (33.9\%) and the remaining 238 people $(66.1 \%)$ female students. The majority of respondents were in the age group $\geq 25$ years as many as 87 students $(24.2 \%)$ and the remaining age group $<25$ years were 273 students $(75.8 \%)$. Most of the respondents were non-economic, and business students were totaling 255 students $(70.8 \%)$ and economic and business students totaling 105 students (29.2\%). Students who have entrepreneurial parents are 115 students (31.9\%), and 245 students $(68.1 \%)$ have parents who are not entrepreneurs. Based on entrepreneurial experience, there were only 90 students (25\%) who had entrepreneurial experience with the remaining 270 students $(75 \%)$ not having entrepreneurship experience.

\section{Test Validity and Reliability}

There are several statements that will be used as a variable indicator in this study for further validity and reliability testing. Test the validity of each statement is done using the Pearson Formula. Based on the results of the validity test with a $95 \%$ confidence level using $\mathrm{r}$ table and $\mathrm{r}$ comparisons, it was obtained that all statements used were valid. This can be seen from the $r$ count value of all statements that vary from 0.476 to 0.982 where overall is higher than the Pearson Table-r that is equal to 0.374 with a significance level of 0.05 . Furthermore, the results of the reliability test using the Cronbach's Alpha value showed that the values obtained ranged from 0.620 to 0.949 where the total was greater than 0.60 so that it was said to be a reliable statement (Sugiyono, 2012).

Table 1. Validity and Reliability Test Results

\begin{tabular}{|l|l|l|l|l|}
\hline Variable & Mean & $\begin{array}{l}\text { Standard } \\
\text { Deviation }\end{array}$ & r & $\begin{array}{l}\text { Cronbach } \\
\text { Alpha }\end{array}$ \\
\hline Locus of Control & & & & \\
The success that I achieved was the result of my own & 3,814 & 1,064 & 0.698 & \\
hard work. & 3,781 & 1,009 & 0,697 & 0,620 \\
Being a leader/entrepreneur depends on my ability. & 3,803 & 1,003 & 0,703 & \\
What I get is not because of luck. & 3,820 & 1,028 & 0,476 & \\
I was able to determine what would happen in my life. & 3,778 & 1,043 & 0,565 & \\
\hline
\end{tabular}




\begin{tabular}{|c|c|c|c|c|}
\hline $\begin{array}{l}\text { The failure that I experienced was a result of my own } \\
\text { actions. }\end{array}$ & & & & \\
\hline $\begin{array}{l}\text { Need for Achievement } \\
\text { I will do my best on difficult assignments related to my } \\
\text { study and work. } \\
\text { I will try hard to improve previous work performance. } \\
\text { I will seek additional responsibility for the work given } \\
\text { to me. } \\
\text { I will try to do better than my friend. }\end{array}$ & $\begin{array}{l}3,803 \\
3,833 \\
3,817 \\
3,775\end{array}$ & $\begin{array}{l}1,003 \\
0,993 \\
1,069 \\
1,046\end{array}$ & $\begin{array}{l}0,768 \\
0,792 \\
0,911 \\
0,828\end{array}$ & 0,844 \\
\hline $\begin{array}{l}\text { Subjective Norms } \\
\text { My family will support me for entrepreneurship. } \\
\text { My friend sees entrepreneurship as a logical choice. } \\
\text { My regional culture encourages entrepreneurship. } \\
\text { Most people in my area see entrepreneurship very } \\
\text { positive. }\end{array}$ & $\begin{array}{l}3,758 \\
3,925 \\
3,869 \\
4,033\end{array}$ & $\begin{array}{l}0,993 \\
0,966 \\
1,014 \\
0.221\end{array}$ & $\begin{array}{l}0,797 \\
0,813 \\
0,913 \\
0,801\end{array}$ & 0,851 \\
\hline $\begin{array}{l}\text { Instrumental Readiness } \\
\text { I have access to capital to start becoming an } \\
\text { entrepreneur. } \\
\text { I have a good social network that can table when I } \\
\text { decide to become an entrepreneur. } \\
\text { I have access to information when I start being an } \\
\text { entrepreneur. }\end{array}$ & $\begin{array}{l}3,778 \\
3,850 \\
3,847\end{array}$ & $\begin{array}{l}1,024 \\
1,029 \\
1,008\end{array}$ & $\begin{array}{l}0,982 \\
0,894 \\
0,982\end{array}$ & 0,949 \\
\hline $\begin{array}{l}\text { Entrepreneurial Intention } \\
\text { I chose a career as an entrepreneur. } \\
\text { I hope to be able to create new businesses in the future. } \\
\text { I will make every effort to start and run my own } \\
\text { business. }\end{array}$ & $\begin{array}{l}3,847 \\
3,883 \\
3,869\end{array}$ & $\begin{array}{l}0.994 \\
0,946 \\
1,033\end{array}$ & $\begin{array}{l}0,919 \\
0,875 \\
0,913\end{array}$ & 0,882 \\
\hline
\end{tabular}

\section{Hypothesis Testing}

After testing the classic assumptions, a regression analysis will be conducted to test the hypotheses proposed in this study, namely the influence of personality factors, contextual factors, and demographic factors on entrepreneurial intentions. The test results for all the hypotheses of this study can be seen in Table 2 below.

\section{Personality Factors}

Based on the results of the hypothesis testing of $\mathrm{H} 1.1$ and $\mathrm{H} 1.2$ it can be seen that all elements in personality factors, namely locus of control and need for achievement, have been proven to have a significant effect on student entrepreneurial intentions with a significance level of 5\% for each element and overall personality factors. The R2 value is 0.122 , which means that the ability of variables contained in personality factors in explaining student entrepreneurship intentions is only $12.2 \%$.

\section{Contextual Factors}

Hypothesis testing shows that $\mathrm{H} 2.1$ and H2.2 are acceptable. Contextual factors, namely subjective norms, and instrumental readiness have a significant effect on student entrepreneurial intentions with a significance level of $5 \%$ both in terms of each element of contextual factors. The following $\mathrm{R} 2$ is 0.145 , which means that there are $14.5 \%$ of contextual factor abilities in explaining student entrepreneurship intentions.

\section{Demographic Factors}

The demographic factors consisting of gender, age, parent education, and experience will be tested by first 
categorizing respondents' answers as dummy variables consisting of code 1 and code 0 . They are related to gender, 1 for men, and 0 for women. Age coding using 1 for ages $\geq 25$ years and 0 for ages $<25$ years. Educational background is encoded with 1 for economics and business and 0 for noneconomics and business. Entrepreneurial parents work encoded with 1 and 0 for not entrepreneurship. Ever experienced entrepreneurship given code 1 and never entrepreneurship given code 0 .
Based on the results of testing the influence of demographic factors on student entrepreneurial intentions it is known that overall demographic factors have no significant effect on entrepreneurial intentions of Sari Mutiara Indonesia University students with a significance level of 5\%. The demographic factors used in this study were gender, age, educational background, parental work, and entrepreneurial experience

Table 2. Hypothesis Test Results

\begin{tabular}{|l|l|l|l|l|l|l|l|}
\hline Variable & Hypothesis & $\mathbf{t}_{\text {cal }}$ & Sig. t & $\mathbf{R}^{2}$ & Adj R $^{2}$ & $\mathbf{F}_{\text {cal }}$ & Sig. F \\
\hline Faktor Kepribadian & & & & & & & \\
Locus of Control & $\mathrm{H} 1.1$ & 2,492 & 0,013 & 0,122 & 0,117 & 24,728 & 0,000 \\
Need for Achievement & $\mathrm{H} 1.2$ & 5,481 & 0,000 & & & & \\
\hline Faktor Kontekstual & & & & & & & \\
Subjective Norms & $\mathrm{H} 2.1$ & 3,353 & 0,001 & 0,145 & 0,140 & 30,216 & 0,000 \\
Instrumental Readiness & $\mathrm{H} 2.2$ & 5,698 & 0,000 & & & & \\
\hline $\begin{array}{l}\text { Faktor Demographic } \\
\text { Gender }\end{array}$ & $\mathrm{H} 3.1$ & 0,618 & 0,537 & & & & \\
$\begin{array}{l}\text { Age } \\
\text { Educational Background }\end{array}$ & $\mathrm{H} 3.2$ & 0,309 & 0,757 & & & & \\
$\begin{array}{l}\text { Parental Work } \\
\text { Entrepreneurial }\end{array}$ & $\mathrm{H} 3.4$ & 0,968 & 0,334 & 0,004 & 0,010 & 0,318 & 0,902 \\
Experience & $\mathrm{H} 3.5$ & 0,515 & 0,607 & & & & \\
\hline
\end{tabular}

\section{Discussion}

The empirical study of community entrepreneurship intention in general and students, in particular, is still extensive opportunity to be followed up because this research is also carried out in minimal scope, namely only at Sari Mutiara Indonesia University. In line with the purpose of this study, it is intended to contribute to providing support to the government to foster the spirit of students to entrepreneurship to reduce unemployment and to accelerate economic growth preceded by examining the factors that influence entrepreneurial intention among students of Sari Mutiara Indonesia University. Today's students are the millennial generation who are expected to become young entrepreneurs today and in the future.
Research on a group of personality factors shows that the elements contained in it are the locus of control and need for achievement have a significant effect on entrepreneurial intention in Sari Mutiara Indonesia University students. The results of this test are consistent with the results of Mat, et al. (2015) which shows that locus of control and need for achievement influence the entrepreneurial intention of mechanical engineering students at Universiti Kuala Lumpur. Likewise, the research is in line with McCleland's (1976) opinion that needs for achievement as a form of psychological motivation influences entrepreneurial intention of the student. Instead, the results of this study are not in line with Indarti and Rostiani (2008) who cannot prove that need for achievement influences student interest in entrepreneurship by using student data 
from three countries, namely Indonesia, Japan, and Norway.

Contextual factors in this study are subjective norms) and instrumental readiness. Based on the research results prove that subjective norms and instrumental readiness of students at Sari Mutiara Indonesia University. The results of this study are in line with Ajzen (2012) and Mat, et al. (2015), which shows that subjective norms influence entrepreneurial intention. Besides, the results of this study are consistent with the results of Singh and Krishna (1994), Kristiansen et al. (2003), Indarti (2004), Indarti and Rostiani (2008), and Darmanto (2014) which showed instrumental readiness influence on entrepreneurial intention.

Furthermore, the demographic factors group consisting of gender, age, educational background, parental work, and entrepreneurship experience are the factors examined in this research model to find out because there are still inconsistencies with the results of previous studies. The test result showed that overall demographic factors did not significantly influence the entrepreneurial intention of Sari Mutiara Indonesia University students.

The results of this study have differences with the research of Indarti and Rostiani (2008) related to the influence of each element used in demographic factors where educational background and work experience for Indonesian students affect entrepreneurial intention, on the contrary age and gender do not affect student entrepreneurship intentions in line with this study. This research is also not in line with Johnson, et. al. (2010) which proves that gender and age affect entrepreneurial intention. Likewise with the research of Suharti and Sirine (2011) which shows that entrepreneurial experience and parental work affect entrepreneurial intention, on the contrary gender and study areas, have no effect.

Gender and age factors tested in this research model prove that students' interest in becoming future young entrepreneurs is not limited by gender. Men and women have the same opportunity to become entrepreneurs in students at Sari Mutiara Indonesia University. Likewise, age does not limit the intention of students to be entrepreneurs, both students aged $<25$ years and $\geq 25$ years.

Educational background factor is often considered as one of the factors that influence entrepreneurial intention. Previous research shows that there is a link between educational background and entrepreneurial intention by Galloway and Keogh (2006). The study proves that students from business faculties have higher entrepreneurial intention than students from the faculty of science and engineering at Heriot-Watt University students. However, this study could not find the influence of educational background on the entrepreneurial intention of students at Sari Mutiara Indonesia University.

The results of this study are in line with those conducted by Suharti and Sirine (2011). One of the things that are likely to be background in the interest of students to try entrepreneurship even though they do not have a business and economic education background because all students from various study programs at Sari Mutiara Indonesia University have been provided with entrepreneurship courses.

Parental work factor was tested in this study as one of the factors that influence entrepreneurial intention because children tend to follow their parents. This study shows that parental work does not affect the entrepreneurial intention of Sari Mutiara Indonesia University students. This research is contrary to Galloway and Keogh (2006) and Suharti and Sirine (2011). Likewise, the factor of entrepreneurial experience in this study did not affect the entrepreneurial intention of students at Sari Mutiara University. This is contrary to the research of Suharti and Sirine (2011). 


\section{Conclusion}

Personality factors, namely locus of control and need for achievement proved to have a significant effect on entrepreneurial intention in the student at Sari Mutiara Indonesia University. Contextual factors, namely subjective norms and need for achievement, have been proven to have a significant effect on the entrepreneurial intention on the student at Sari Mutiara Indonesia University. Demographic factors, namely gender, age, educational background, parental work, and entrepreneurship experience proved to have no significant effect on the entrepreneurial intention of students at Sari Mutiara Indonesia University.

\section{References}

Ajzen, I. 2012. The Theory of Planned Behavior. New York: Lawrence Erlbaum Associates

Badan Pusat Statistik, www.bps.go.id, accessed 6 April 2018

Darmanto. S., \& Wahyudi, S. 2014. Developing Intention and Entrepreneurial Behavior Through the Mediating Role of Entrepreneurial Self Efficacy Maturity (An Empirical Study on University Students in Semarang, Indonesia.

http://dx.doi.org/10.2139/ssrn.2395 090, accessed 5 April 2018

Galloway. L., Kelly, \& S., Keogh, W. 2006. Identifying Entrepreneurial Potential in Students. Working Paper No. 006, National Council for Graduate Entrepreneurship

Indarti, N. 2004. Factors Affecting Entrepreurial Intentions Among Indonesian Students. Jurnal Ekonomi dan Bisnis 19 (1): 57-70

Indarti, N. \& Rostiani, R. 2008. Intensi Kewirausahaan Mahasiswa: Studi Perbandingan Antara Indonesia, Jepang, dan Norwegia. Jurnal
Ekonomi dan Bisnis Indonesia 23 (4): $1-26$

Johnson, K. A., Andersen, B. K., DavidgePitts, J. \& Ostensen-Saunders, M. 2010. Identifying ICT Entrepreneurship Potential in Students. Proceedings Informing Science \& IT Education Conference (InSITE), Italy, 21-24 Juni

Harian Kompas, www.kompas.com, accessed on 5 April 2018

Hendro. 2011. Dasar-dasar Kewirausahaan. Jakarta: Erlangga

Kasmir. 2011. Kewirausahaan. Edisi Revisi. Jakarta: Rajagrafindo Persada

Kreitner, R. \& Kinicki, A. 2005. Perilaku Organisasi (Organizational Behavior). Jakarta: Salemba Empat

Kristiansen, S., Furuholt, B., \& Wahid, F. 2003. Internet Cafe Entrepreneurs: Pioneers in Information Dissemination in Indonesia. The International Journal of Entrepreneurship and Innovation 4 (4): 251-263

Kuratko, D. F. 2009. Entrepreneurship, Theory, Process, Practice. SouthWestern: South-Western Cengage Learning

Mat, S. C., Maat, S. M., \& Mohd, N. 2015. Identifying Factors that Affecting the Entrepreneurial Intention among Engineering Technology Students. Procedia-Social and Behavioral Sciences 211: 1016-1022

McClelland, D.C. \& Burnham, D.H. 1976. Power is the Great Motivator. Harvard Business Review, 54, 159166

Robbins dan Judge. 2007. Perilaku Organisasi. Buku 1 dan 2. Jakarta: Salemba Empat

Singh, K. A. \& Khrisna, K. V. S. M. 1994. Agricultural Entrepreneurship: the Concept and Evidence. Journal of Entrepreneurship 3 (1): 97-111

Sugiyono. 2012. Metode Penelitian Kuantitatif dan Kuantitatif dan R \& 
D. Cetakan ke-19. Bandung :

Alfabeta

Suharti, Lieli dan Hani Sirine. 2011.

Faktor-faktor yang Berpengaruh

Terhadap Niat Kewirausahaan

(Entrepreneurial Intention) (Studi

Terhadap Mahasiswa Universitas

Kristen Satya Wacana, Salatiga).

Jurnal Manajemen dan

Kewirausahaan 13 (2): 124-134

Suryana. 2008. Kewirausahaan. Jakarta:

Salemba Empat

Zimmerer, T. W., \& Scarborough, N. M.

2008. Kewirausahaan dan

Manajemen Usaha Kecil. Jakarta 